\title{
Production and Evaluation of Biscuits from Lima Bean (Phaseolus Lunatus), Sorghum and Wheat Flour Blends.
}

\author{
*Adebayo S.F ${ }^{1}$, Okoli E.C ${ }^{2}$. \\ ${ }^{I}$ Department of Food Technology, The Federal Polytechnic, Ado-Ekiti. Ekiti State, Nigeria \\ ${ }^{2}$ Department of Food Science and Technology. Ebonyi State University, Abakaliki. Ebonyi State, Nigeria. \\ Corresponding Author: Adebayo S.F
}

\begin{abstract}
Composite flour was produced from the sprouts of lima bean, sorghum and wheat. Their physicochemical properties were determined in the following proportions 50:15:35; 40:25:35; 30:35:35; $20: 45: 35 ; 10: 55: 35$. The sensory attributes of the biscuits produces from the composite flour compared favorably with that of 100\% wheat flour. The sensory analysis was assessed using a 9 point hedonic scale with 9 point for like extremely and 1 for dislike extremely with 20 untrained panelists. Analysis of significance difference in the result was performed using the analysis of variance and the means were separated using least significant test. The proximate composition of the composite flour were found to be higher than that of 100\% wheat flour and were significantly different from each other $(P<0.05)$. The water absorption capacity, Oil absorption capacity, bulk density, emulsion capacity and foaming capacity ranged from 94.30-96.00; 96.2396.89; 0.54-1.16; 33.40-40.00 and 84.00-97.00 respectively. Amylose ranged between 13.28-26-61 \% and amylopectin 73.89-86.72\%. The sensory score showed overall preference for 50:15:35 of lima bean, sorghum and wheat flour respectively and the substitution could be recommended for use in the bakery industry.
\end{abstract}

Keywords: Composite flour; biscuit; lima bean.

\section{Introduction}

The consumption of bread and other bakery goods such as biscuits, doughnuts and cakes produce from wheat flour is very popular, but the low protein content of wheat flours which is the most vital ingredients used for the production of different kinds of baked goods has been major concern in its utilization (Young, 2001). Biscuits as one of the most popular cereals snacks, very common among children especially in Nigeria, which are ready to eat, convenient and inexpensive food, containing digestive and dietary principle are of vital importance. It would therefore be of economic advantage if wheat flour can be replaced with flour from legumes and cereals thereby reducing the reliance on its importation and thus enhancing the industrial utilization of local crops with high protein values to replace a portion of wheat flour thereby increasing the nutritive properties of the food in question. Biscuits have been suggested as a better use of composite flour than bread due to their ready to eat form, wide consumption relatively long shelf life and good eating quality (Okpala and Chinyelu, 2011).

Efforts has been made to promote the use of composite flour in which locally grown crops with high protein values replaces a portion of wheat flour. Lima beans (Phaseolus lunatus) are plants producing fruits that are starchy at maturity and need processing before consumption. Lima bean seed contain between 22-25\% proteins and make a significant contribution to the protein and energy requirement of many Nigeria. Lima beans are rich in niacin, thiamine and riboflavin (Sathe et al., 1984). They are said to contain high levels of potassium, phosphorus, calcium and iron (Ologhobo and Fetuga, 1984; Osagie et al., 1996). The role of lima bean as a source of protein is however affected by several factors including low protein digestibility (Aletor and Fetuga, 1984), flatulence and the presence of numerous anti-nutritional constituents (Sanchez et al., 1966) which made up the most important single factor affecting its utilization.

Sorghum (Sorghum bicolor (L) Moench) is known under a great many names: milo, guinea corn in West Africa. It is used for flours, porridge and malted distilled into beverages. It is also a significant crop for animal feed. Sorghum originated in Northern African and is now cultivated widely in tropical and subtropical regions. It is typically an annual, but some cultivars are perennial. Sorghum contains between 11.30-13.00\% proteins, fat $1-3.30 \%$, dietary fibre $3-6.00 \%$ and carbohydrates $74.63 \%$. Sorghum can be substituted for wheat in flour varieties of baked goods. It is neutral, sometimes sweet; flavor and light color make it easily adaptable to a variety of dishes. Sorghum improves the texture of recipes and digests more slowly with a lower glycemic index, so it sticks a bit longer than some other flours or flour substitutes. Sorghum is high in antioxidants, which are believed to help lower the risk of cancer, diabetics, heart diseases and some neurological diseases. The wax 
surrounding the sorghum grain contains compound called policosanols, which may have an impact on human cardiac health (Varady et al., 2003). Composite flour from lima bean, sorghum and wheat has not been exploited in bakery as well as snacks and complementary food formulation. In this study, the use of germination was employed in the lima bean and sorghum as composite flour in biscuit production.

Source of Materials.

\section{Materials And Methods.}

Lima beans, sorghum and wheat used were purchased from LIC Agriculture Department of the Ministry of Agriculture. Ado-Ekiti, Ekiti State.

\section{Cleaning}

The sample lima beans, sorghum and wheat were cleaned to remove husks, stones, and cobs, damaged and colored seeds. These were achieved through winnowing, sieving and hand picking subsequently the seeds were packaged and store in a refrigerator condition at $10 \pm 2{ }^{\circ} \mathrm{C}$ for further processing and analyses.

Germination

Germination was carried out according to the method described by Ariahu et al., (1999). The seeds were washed in $5 \%(\mathrm{w} / \mathrm{v})$ sodium chloride solution to suppress mould growth and soaked in tap water in ratio of $1: 3(\mathrm{w} / \mathrm{v})$ grains for $12 \mathrm{hr}$ at room temperature $\left(32 \pm 2{ }^{\circ} \mathrm{C}\right)$. The water was drained and the samples spread on jute bags, covered with damp cotton and allowed to germinate for $24 \mathrm{hrs}$. At the end of germination, root hairs were removed from the germinated seeds. The seeds were dried at $60^{\circ} \mathrm{C}$ in an oven to a moisture content of about $10 \%$ and ground in to flour using attrition mill (globe p 44 Chima). Each flour sample was passed through a $0.5 \mathrm{~mm}$ mesh size sieve. They were packaged in an air tight polyethylene bags, store in plastic containers with lids and stored in cool dry place for the next analyses.

Production of biscuits

The flour blends were homogeneously prepared; lima bean, sorghum, and wheat flours in proportion as 50:15:35; 40:25:35; 30:35:35; 20:45:35; $10: 55: 35$ and $100 \%$ wheat flour as control. The blends were subjected to chemical composition, functional properties and sensory assessment determination. The method described by Oyewole et al., (1996) was adopted to process the flour samples into biscuits. The biscuits were cooled and wrapped in air tight polyethylene bags. Sensory evaluation were determined with a 20 member semi-trained panelist using 9-point Hedonic scale ranging from 1(extremely disliked) to 9 (extremely liked). The physical properties were color, crispness, flavor and taste. The results obtained were subjected to statistical analysis (ANOVA) and the means compared and separated using the least significant difference (LSD).

Sample analysis.

The chemical composition of the raw samples and the composite flours were determined according to AOAC (2000). Water absorption capacity (WAC) and oil absorption capacity (OAC) were determined according to the method described by Sasulki et al., (1996), emulsion capacity were determined using the method described by Yasumatsu et al., (1992), foaming capacity was determined according to the method described by Narayana and Narsinga (1992) and swelling power was determined by Akpada and Miachi (2001) method.

\section{Results And Discussion.}

The results of the proximate composition of lima beans, sorghum and wheat grains are shown in Table 1. The moisture content was not significantly different from each other in the range of (7.00-7.50\%) relative for cereals and legumes. The ash content was higher in lima bean and lower in wheat. The protein content ranged between $(8.50-22.63 \%)$ significantly higher in lima bean and lower in sorghum grain. Crude fibre content was higher in lima beans $(6.45 \%)$ and lower in wheat. The results indicate lima beans to be more nutritious than the two cereals examined.

TABLE 1: The chemical composition of Lima beans, sorghum and wheat grain.

\begin{tabular}{|c|c|c|c|c|c|c|}
\hline Food sample & $\begin{array}{l}\text { Moisture } \\
(\%)\end{array}$ & $\begin{array}{l}\text { Ash } \\
(\%)\end{array}$ & $\begin{array}{l}\text { Fat } \\
(\%)\end{array}$ & $\begin{array}{l}\text { Protein } \\
(\%)\end{array}$ & $\begin{array}{r}\text { Crude fiber } \\
(\%)\end{array}$ & $\begin{array}{r}\text { Carbohydrate } \\
(\%)\end{array}$ \\
\hline Sorghum & $7.50^{\mathrm{a}}$ & $2.50^{\mathrm{b}}$ & $4.25^{\mathrm{b}}$ & $8.50^{b}$ & $2.15^{\mathrm{b}}$ & $75.10^{b}$ \\
\hline Wheat & $7.00^{\mathrm{a}}$ & $1.55^{\mathrm{c}}$ & $4.30^{\mathrm{a}}$ & $9.65^{\mathrm{c}}$ & $1.82^{\mathrm{c}}$ & $75.68^{\mathrm{a}}$ \\
\hline Lima bean & $7.40^{\mathrm{a}}$ & $4.75^{\mathrm{a}}$ & $3.49^{\mathrm{c}}$ & $22.63^{\mathrm{a}}$ & $6.45^{\mathrm{a}}$ & $55.28^{\mathrm{c}}$ \\
\hline
\end{tabular}

Means with different superscript within the same column are significantly different $(\mathrm{p}<0.05)$. 
Table 2 shows the chemical composition of the composite flour in the following proportions; A indicating 50:15:35; B 40:25:35; C 30:35:35; D 20:45:35 and E 10:55:35 level of substitution of lima beans to sorghum and wheat flour respectively. The proportion of wheat flour was the same and lima beans with sorghum rationed. The results show that the moisture content was between $7.50-8.80 \%$ which is relative to flour products, this indicates that the flour products are stable (Eke-Ejifor and Owuno, 2012). The ash content ranged between 0.50-4.00\% higher than wheat/ yam composite flour (Eke-Ejifor and Owuno, 2012) and ash content of sweet potato/ soybean flour (Abayomi et al ., 2013). This shows the composite flour contain appreciable amount of minerals. Sample A (50:15:35) has ash content which was significantly higher than sample C, D and E. The protein content of the sample with substitution B was significantly better than other substitution and least in D (20:45:35). The crude fibres were not significantly better than each other. The amylase content of raw materials is an important factor regarding the end use properties of various products such as bakery products (Sievert and Lausanne, 1993). The amylase content was $13.28-26.61 \%$ lowers than the value for composite flour of wheat / yam blends (Eke-Ejifor and Owuno, 2012). This shows that composite flour of lima bean, sorghum and wheat flour blends will be better used in noodles. Raja and Ramakrishma (1990) reported that heat treatment caused a reduction in amylase content of starch -based products and germination has also reduce the amylase content of the sampled grain to produce composite flour. Amylopectin content ranged from 73.39-86.72\%. A decrease in amylose with an increase in amylopectin means that one is a function of the other and both properties are important in food preparations and development.

Table 2: Chemical composition of composite flours of lima beans, Sorghum and Wheat flour blends for biscuits.

\begin{tabular}{lccccc}
\hline Chemical composition & A & B & C & D & E \\
\hline Moisture (\%) & $8.80^{\mathrm{a}}$ & $7.50^{\mathrm{b}}$ & $7.80^{\mathrm{b}}$ & $8.60^{\mathrm{a}}$ & $8.40^{\mathrm{a}}$ \\
Protein $(\%)$ & $18.85^{\mathrm{a}}$ & $19.33^{\mathrm{a}}$ & $15.89^{\mathrm{b}}$ & $14.10^{\mathrm{c}}$ & $13.52^{\mathrm{d}}$ \\
Ash $(\%)$ & $4.00^{\mathrm{a}}$ & $3.25^{\mathrm{b}}$ & $2.25^{\mathrm{c}}$ & $1.00^{\mathrm{d}}$ & $0.50^{\mathrm{d}}$ \\
Crude fiber (\%) & $4.23^{\mathrm{a}}$ & $4.36^{\mathrm{a}}$ & $4.39^{\mathrm{a}}$ & $4.40^{\mathrm{a}}$ & $4.46^{\mathrm{a}}$ \\
Carbohydrate (\%) & $60.83^{\mathrm{a}}$ & $62.09^{\mathrm{d}}$ & $65.58^{\mathrm{c}}$ & $68.84^{\mathrm{b}}$ & $68.90^{\mathrm{b}}$ \\
Amylose (\%) & $21.83^{\mathrm{a}}$ & $19.83^{\mathrm{b}}$ & $17.56^{\mathrm{c}}$ & $16.61^{\mathrm{d}}$ & $13.28^{\mathrm{e}}$ \\
Amylopectin $(\%)$ & $78.17^{\mathrm{e}}$ & $80.17^{\mathrm{d}}$ & $82.44^{\mathrm{c}}$ & $83.39^{\mathrm{b}}$ & $86.72^{\mathrm{a}}$ \\
\hline
\end{tabular}

Means with different superscript within the same column are significantly different $(\mathrm{p}<0.05)$.

Table 3 shows the functional properties of lima beans, sorghum and wheat flour blends. The water absorption capacity was highest in sample A $(96.00 \%)$ and lower in sample D $(94.00 \%)$, the level of water absorption capacity increases as the level of the lima bean in the blend increases. Sample A absorbs more water than other sample. Water absorption capacity is the ability of flour particles to entrap large amount of water such that exudation is prevented, this also has implication on viscosity Niba et al., (2001). Water absorption capacity is also important in bulking and on consistency. The oil absorption capacity ranged between (95.66-96.89 \%) and the level increased as the level of sorghum increases in the blends, this shows that the blends would be useful in bakery products where hydration to improve handling is desired and in ground meat, doughnut and pancakes were oil absorption capacity property is of prime importance Mepha et al., (2007). Sample E has the highest oil absorption capacity and sample $C$ the least. The bulk density of the flour ranged between $0.543-1.157$ $\mathrm{cm}^{3}$ and higher in sample $\mathrm{C}\left(1.157 \mathrm{~cm}^{3}\right)$ and lowest in sample $\mathrm{E}\left(0.543 \mathrm{~cm}^{3}\right)$. The bulk density decreases as the level of substitution of lima bean decreases in the blend.

The foaming capacity increases as the level of substitution of lima bean decreases in the blend. Sample $\mathrm{E}$ has the highest foam $(97.00 \mathrm{ml})$ and least value in sample $\mathrm{A}(84.00 \mathrm{ml})$, this means that sample E can serves as a foaming agent than sample A in food formulation. The emulsion capacity ranged between 33.40-40.00\% Sample with the highest level of sorghum on substitution (E) has the highest level of oil absorption capacity, foaming capacity and emulsion capacity respectively. Sample E which depicts high level of foam may find wider applications in baked and confectionery products. Product formulation is related to the rate of decrease in the ratio of the surface tension of air to water interface caused by absorption of protein molecules. With lower amylose content $(13.28 \%)$ in sample E, a factor that influence the clarity of starch pastes, lower amylase starch are easily dispersed, increasing transmittance and clarity in confectioneries.

Table 3: Functional properties of the composite flour for biscuits.

\begin{tabular}{lccccc}
\hline Parameters & Sample A & Sample B & Sample C & Sample D & Sample E \\
\hline Water absorption capacity & $96.00^{\mathrm{a}}$ & $95.00^{\mathrm{b}}$ & $94.00^{\mathrm{c}}$ & $94.00^{\mathrm{c}}$ & $94.30^{\mathrm{c}}$ \\
Oil absorption capacity & $96.62^{\mathrm{b}}$ & $96.23^{\mathrm{b}}$ & $95.66^{\mathrm{c}}$ & $96.82^{\mathrm{a}}$ & $96.89^{\mathrm{a}}$ \\
Bulk density & $0.59^{\mathrm{b}}$ & $0.56^{\mathrm{b}}$ & $1.15^{\mathrm{a}}$ & $0.54^{\mathrm{c}}$ & $0.54^{\mathrm{c}}$ \\
Foaming capacity & $84.00^{\mathrm{d}}$ & $96.00^{\mathrm{b}}$ & $95.60^{\mathrm{c}}$ & $95.50^{\mathrm{c}}$ & $97.00^{\mathrm{a}}$ \\
Emulsion capacity & $39.20^{\mathrm{b}}$ & $35.56^{\mathrm{d}}$ & $36.00^{\mathrm{c}}$ & $33.40^{\mathrm{e}}$ & $40.00^{\mathrm{a}}$ \\
Swelling capacity & $4.24^{\mathrm{c}}$ & $6.35^{\mathrm{a}}$ & $5.21^{\mathrm{b}}$ & $3.23^{\mathrm{d}}$ & $2.01^{\mathrm{e}}$ \\
\hline
\end{tabular}

DOI: $10.9790 / 2402-1107014448$

www.iosrjournals.org 46 | Page 
Means with different superscript within the same column are significantly different $(\mathrm{p}<0.05)$

Sensory evaluation

Table 4 shows the sensory evaluation results of the substitutions of lima bean sorghum wheat blends with wheat flour biscuit as the control. Biscuits produced compare favorably with the control in terms of color which ranged from2.1-3.1 having the color of sample C (biscuits) as the highest and sample B has a dull color. The crispness decreases with reduction level of lima bean substitution and ranged from 2.4-2.8. Sample C and E were less crisp and B and D compared favorably with F the control sample.

Taste is the primary factor that determines the acceptability of any product which has the highest impact as far as market success of product is concerned. The taste ranges from 2.4-3.0. Sample D compare favorably with the control. The overall acceptability of the sample gave sample D to be best of the blends $(20,45,35)$

Table 4: Sensory evaluation of biscuits.

\begin{tabular}{lcccccc}
\hline Attributes & A & B & C & D & E & F \\
\hline Color & 2.3 & 2.1 & 3.1 & 2.9 & 2.7 & 2.6 \\
Crispness & 2.6 & 2.8 & 2.4 & 3.3 & 2.4 & 2.8 \\
Flavor & 2.9 & 2.7 & 3.2 & 3.6 & 2.8 & 3.6 \\
Taste & 2.5 & 2.4 & 3.0 & 2.7 & 2.6 & 3.1 \\
Mean & 2.6 & 2.6 & 2.9 & 3.3 & 2.7 & 3.2 \\
Overall acceptability & 3.8 & 3.0 & 3.2 & 3.8 & 3.3 & 4.0
\end{tabular}

\footnotetext{
$\mathrm{A}=50: 15: 35=$ Sprouted lima bean, sprouted sorghum and wheat flour

$\mathrm{B}=40: 25: 35=$ Sprouted lima bean, sprouted sorghum and wheat flour

$\mathrm{C}=30: 35: 35=$ Sprouted lima bean, sprouted sorghum and wheat flour

$\mathrm{D}=20: 45: 35=$ Sprouted lima bean, sprouted sorghum and wheat flour

$\mathrm{E}=10: 55: 35=$ Sprouted lima bean, sprouted sorghum and wheat flour

$\mathrm{F}=100 \%$ wheat flour
}

\section{Conclusion}

The findings of this research revealed that the biscuits produce with lima bean flour substitution up to $10 \%$ was suitable for biscuit production and at $40 \%$ lima bean substitution gave the highest protein content which shows that lima bean has contributed nutritionally making the biscuit superior. The high protein content in lima bean sorghum wheat flour supplemented food would be of nutritional importance in most developing countries like Nigeria where many people hardly afford high proteinous foods because of high cost. Therefore it can be recommended that the addition of lima flour to cereals has enhanced the nutritional composition of the biscuits, the incorporation will also help to reduce the foreign exchange on wheat importation.

\section{References}

[1] A.O.A.C (2005). Official Method of Analysis. $17^{\text {th }}$ Edition, Association of Analytical Chemist. Washington DC.

[2] Abayomi H.T, Oresanya T.O, Opeifa A.O and Rasheed T.R (2013). Quality evaluation of cookies produced from blends of sweet potato and fermented soybean flour. Food, International Journal of Biological Veterinary and Agricultural Engineering. Vol. 7: 1722.

[3] Akpada M.I and Miachi O. E (2001). Proximate composition and selected functional properties of Detarium microcarpum. Plant Foods Human Nutri. 56: 297-302.

[4] Ariahu C.C, Ukpabi U and Mbajunwa K. O (1999). Production of African Breadfruit (Treculia africana) and soybean (Glycine max) baked food formulation I : Effect of germination and fermentation on nutritional and organoleptic quality. Plant Food Human Nutrition. 54: 123-266.

[5] Aleto V.A and Fetuga B.I (1984). Influence of raw and cooked lima bean meals on performance, nutrient utilization and disaccharide activities on rat. Nutri. Rept. International 29(3): 571.

[6] Eke-Ejiofor J and Owuno F (2012). Functional and Pasting properties of Wheat / Three-leaves Yam (Dioscorea dumentorum) composite flour blend. Journal of Agric and Biological Sci. Vol 3(4):330-335.

[7] Mepha H.D, Akpapunam M.A and Berepupo, H.A(2007). Production of non-fermented beverages from ripe Banana Chemical content and sensory characteristics. Discovery and innovation 2(1): 85-91.

[8] Narayana K and Narsinga Rao M.S (1992). Functional properties of raw and heat processed winged bean (Psophocarpus tertragonolobus) flour. Journal Food Sci. 47: 534-538.

[9] Niba L.L, Bokanga M.M, Jackson, F.L, Schlimmme D.S and Li B.W (2001). Physicochemical properties and starch granular characteristics of flour from various Manihot esculenta (Cassava) genotypes. Journal of Food Science. 67(5): 122-130.

[10] Ologhobo A.D and Fetuga B.L (1984). Distribution of Phosphorus and Phytate in some Nigeria varieties of legumes and some effects on processing. Journal of Food Sci. 49: 199-201.

[11] Osagie A.U, Muzquiz, M, Burbano C., Cuadrado C, Ayetand Castano A (1996). Some anti-nutritional constituents in ten staple foods grown in Nigeria. Trop. Sci. 36: 109-115.

[12] Offia Olua B.I and Egbe V.O (2012). Development and Quality Evaluation of Sprouted Tiger-nut Wheat Biscuit. In the proceeding of the $36^{\text {th }}$ Annual conference of NIFST 2012. Pg 61-62.

[13] Olapade A.A, Aworh O.C and Oluwole O.B (2011): Quality Attribute of Biscuit from Acha (Digitaria exilis) Flour Supplemented with Cowpea (Vigna unguiculata) Flour. Africa Journal of Food Science and Technology. Vol. 2(9): 198-203.

[14] Okpala L.C and Chinyelu V.O (2011). Physicochemical, Nutritional and Organoleptic evaluation of cookies from pigeon pea. Journal of Food, Agriculture, Nutrition and Development.

[15] Oyewole O.B., Sanni L. O and Ogunjobi M.A (1996). Production of Biscuits using Cassava flour. Nig. Food Journal. 14: 24-29.

[16] Raja K.C.M and Ramakrishma S.U (1990). Composition and pasting characteristics of plain-dried and parboiled cassava (Manihot esculenta cranzt). Food Chem. 38: 79-88. 
[17] Sanchez R, Tankerm C and Murphy E.L (1966). The development of the flatulence principle in the maturing bean. $8^{\text {th }}$ Dry Bean Research Conference. Bellair Michigan. Pp 53-58.

[18] Sathe S.K, Desphande S.S and Salunkhe D.K (1984). Dry beans of Phaseolus. A review part 1. Chemical composition: Carbohydrate, fibre, minerals, Vitamin and lipid. CRC. Crit. Rev. Food Sci. Nutri. 21: 41-93.

[19] Sasulki F.W, Garrant M.D and Slinkard A.E (1996). Functional properties of fern legume flour. Inst. Food Sci. Technol. Journal. 9: 66-69.

[20] Sievert D and Lausanne J.H (1993). Determination of amylase by differential Scanning Calorimetry. Starch/ Starke. 451 (4): 136139 .

[21] Varady K.A, Wang Y, Jones P.J (2003). Role of Policosanols in the prevention and treatment of cardiovascular disease. Nutria. Rev 61 (11): 376-83

[22] Yasumatsu K.I, Sawada K, Moritaka S, Misaki M , Tado J and Woda T (1992). Whipping and emulsifying properties of sorghum product. Journal Agric. Biol. Chem. 36:719-725.

[23] Young, J (2001). Functional bakery products: Current directions and future opportunities. Food Industrial Journal. 4: 136-144.

Adebayo S.F. "Production and Evaluation of Biscuits from Lima Bean (Phaseolus Lunatus), Sorghum and Wheat Flour Blends." IOSR Journal of Environmental Science, Toxicology and Food Technology (IOSR-JESTFT) 11.7 (2017): 44-48. 